\title{
Indigenous Knowledge Masyarakat Etnis Karo terhadap Pengelolaan Tumbuhan Hutan di Desa Lingga Kabupaten Karo
}

\author{
Agung Suharyanto*1 \\ Ramot Simon Hans Kristian Harianja ${ }^{2}$, Putri Wijayanti Ndraha², Ika Santi Kasima \\ Saragih $^{2}$, Karen Fransiska Sipayung², Nurhasanah Harahap ${ }^{2}$, Richard Daniel Nababan²
}

1) Program Studi Ilmu Pemerintahan, Fakultas Ilmu Sosial dan Ilmu Politik Universitas Medan Area, Indonesia

2) Program Studi Pendidikan Antropologi, Fakultas Ilmu Sosial Universitas Negeri Medan, Indonesia

Diterima: Februari 2019; Disetujui: Maret 2019; Dipublish: April 2019

*E-mail: agungsuharvanto@staff.uma.ac.id

\begin{abstract}
Abstrak
Tujuan dilakukannya penelitian ini adalah untuk mengetahui Indigenous Knowledge etnis Karo terhadap pemanfaatan tumbuhan hutan dan untuk mengetahui pengolahan tumbuhanhutan di Desa Lingga sebagai pengobatan tradisonal. Penelitian ini menggunakan metode penelitian kualitatif dengan pendekatan deskriptif. Indigenous Knowledge yang dimiliki masyarakat Etnis Karo ini bersifat turun temurun, yang diwariskan langsung dari nenek moyang mereka.Uniknya meskipun diwariskan secara turun temurun, belum tentu semua anggota keluarga dapat memiliki keahlian ini, tetap saja hanya orang-orang tertentulah dalam keluarga tersebut mewariskan kemampuan dalam pembuatan obat-obat tradisional ini. Terdapat berbagai macam obat-obatan yang diracik oleh masyarakat etnis Karo dari tumbuhan hutan di sekitar Desa Lingga dengan menggunakan cara, alat dan bahan sederhana yang digunakan menjadi obat untuk mengatasi berbagai jenis penyakit, mulai dari penyakit ringan, seperti sakit kepala, batuk, masuk angin, dll, hingga kepada penyakit yang memerlukan penanganan serius, seperti luka dalam akibat kecelakaan. Adapun jenis obat-obatan yang dimaksud antara lain: sembur, obat dalam atau luka dalam, parem, tawar, obat mata, obat cacar, membersihkan kulit bayi baru lahir, obat luka, menjaga pinggang bayi saat belajar berjalan, dan obat terkilir.
\end{abstract}

Kata Kunci: Indigenous Knowledge, Etnis Karo, Tumbuhan Hutan

\begin{abstract}
Purpose of this study is to determine the Indigenous Knowledge ethnic Karo to the use of plants Forest and to know the processing plants Forest in the village Lingga as the treatment of traditional. This study using qualitative research methods with descriptive approach. Indigenous Knowledge owned ethnic communities Karo this is hereditary, which is inherited directly from their ancestors. Uniquely although inherited hereditary, not necessarily all family members can have the expertise of this, still only people tertentulah in the family pass on the ability in the manufacturing of traditional medicines this. There are a variety of drugs formulated by ethnic communities Karo of herbs Forest around the village Lingga by using the way, tools and simple ingredients used to be drugs to overcome the different types of disease, ranging from mild disease, such as headache, cough, colds, etc., up to the disease that requires handling serious, such as the wound in the result of an accident. as for the type of drugs is among others: blurted, drugs in or cuts deep parem, fresh, eye drug, drug smallpox, clean skin the newborn, drug wound, keeping the waist baby when learning run, and drug sprained.
\end{abstract}

Keywords: indigenous knowledge, Ethnic Karo, Herbs Forest

How to Cite: Suharyanto, A. Harianja, R.S.H.K. Ndraha, P.W. Saragih, I.S.K. Sipayung, K.F. Harahap, N. \& Nababan, R. D. (2019). Indigenous Knowledge Masyarakat Etnis Karo Terhadap Pengelolaan Tumbuhan Hutan Di Desa Lingga, Kabupaten Karo. Journal of Education, Humaniora and Social Sciences (JEHSS). 1 (3): 162-169. 


\section{PENDAHULUAN}

Sumatera Utara merupakan salah satu Provinsi di Indonesia yang terdiri dari masyarakat multicultural. Masyarakat adat (suku bangsa) yang berdiam di Sumatera Utara memiliki bahasa, kesenian, kerajianan tangan, obat tradisional dari alam, proses penyembuhan, proses memasak, proses pemanfaatan alam, dan lain sebagaianya. Pada setiap etnis tentunya pengetahuan tradisional atau indigenous knowledge telah menjadi salah satu bagian terpenting dalam kehidupan bahkan telah menjadi identitas diri (budaya) yang memiliki nilai kepercayaan.

Dewasa ini, pelestarian terhadap pengetahuan tradisional sudah semakin menurun, seiring perubahan kehidupan yang terjadi, hal ini disebabkan karena pewarisan yang dilakukan secara lisan dan tidak ada dokumentasi pendukung lainnya. Bila keadaan ini berlangsung secara berkelanjutan, maka dikhawatirkan akan menghilang seiring berjalannya waktu. Padahal pengetahuan tradisional merupakan sebuah aset yang berharga dan bermanfaat bagi kehidupan.

Berdasarkan penelitian yang dilakukan oleh Aini (2012) bahwa penting untuk melindungi pengetahuan tradisional karena pengetahuan tradisional yang di Indonesia berpotensi untuk memberikan keuntungan segi ekonomis yang secara faktual dimanfaatkan oleh negara-negara maju untuk industri obat-obatan dan kosmetik. Jadi, sangat penting bagi kita untuk peduli terhadap aset berharga ini yang sudah diwariskan oleh nenek moyang atau leluhur kita.

Permasalahan yang dikaji adalah tentang indigenous knowledge atau pengetahuan lokal etnis Karo yang berada di Dataran Tinggi Karo, tepatnya di Desa Lingga, Kabupaten Karo. Masyarakat di Etnis Karo terkenal dengan beragam tradisi unik, termasuk di dalamnya cara pengobatan tradisional yang masih digunakan sampai saat ini meskipun teknologi telah berkembang dan dapat dikatakan maju. Sumber pembuatan obat-obat tradisional ini diambil dari alam sekitar mereka. Oleh karena itu, dapat dikatakan bahwa budaya masyarakat ini tidak terlepas dari alam yang di dalamnya termasuk hewan dan tumbuhan.

Pengobatan tradisional di etnis ini dikatakan unik karena obat-obat yang telah diracik hanya ditemukan di daerah tertentu di Tanah Karo. Tujuan dilakukannya penelitian ini adalah untuk mengetahui Indigenous Knowledge etnis Karo terhadap pemanfaatan tumbuhan hutan dan untuk mengetahui pengolahan tumbuhan hutan di Desa Lingga sebagai pengobatan tradisonal. Sebagai contohnya dalah oukup yang merupakan salah satu pengobatan tradisional yang sangat popular di kalangan masyarakat Karo dan bahkan di luar masyarakat Karo (Simarmata \& Feriel, 2015). Masyarakat etnis Karo yang tinggal di Desa Lingga memiliki pengetahuan lokal dalam memanfaatkan tumbuhan hutan yang ada dilingkungan sekitar mereka (Pandapotan, Khairat \& Syahril, 2018)

Tumbuhan hutan tersebut diracik hingga menjadi sebuah obat yang dapat dimanfaatkan untuk mengobati berbagai penyakit, misalnya parem yang diracik dari bawang merah, bawang putih, bahing, buah pala, kulit jeruk purut (untuk bayi ditambahkan kencur dan kemiri, sedangkan untuk ibu yang sudah melahirkan ditambahkan lada hitam dan bahing diperbanyak), penyakit yang dapat di obati dari parem yaitu sakit kepala, masuk agin, sakit perut, menyembuhkan pegal-pegal pengaruh kerja berat, pemulihan terkilir. Pada ibu yang baru melahirkan parem ini di gunakan untuk memulihkan stamina dan menjaga kehangatan tubuh dari si ibu, pada anak kecil atau bayi parem digunakan untuk menjaga kehangatan tubuh dan memperkuat imun tubuh karena anak bayi masih akan rentang terkena penyakit dan paparan dari luar.

Penelitian Pandapotan, Khairat \& Syahril. (2018), tentang Inventarisasi Kearifan Lokal Etnis Karo dalam Pemanfaatan Etnobotani di Kabupaten Karo, mengatakan bahwa berbagai bentuk kearifan lokal Etnis Karo dalam pemanfaatan berbagai jenis tumbuhan lokal, pengolahan secara medikal, pangan, kosmetika, ritual, dan papan. Setidaknya terdapat 218 jenis tumbuhan lokal Etnis Karo yang tumbuh dan diketahui Etnis Karo khasiat dan kegunaannya. Tumbuhan lokal untuk medikal sejumlah 183 jenis, untuk bahan kuliner sejumlah 53 jenis, untuk kosmetika sejumlah 32 jenis, untuk magis sejumlah 27 jenis, dan untuk peratalan rumah tangga (papan) sejumlah 7 jenis. Tumbuhan/tanaman lokal yang berfungsi secara etnobotani ada yang memiliki fungsi ganda, sehingga total tumbuhannya bisa saja melebihi jumlah jenis tumbuhan/tanaman 象 http://mahesainstitute.web.id/ojs2/index.php/jehss 
lokal yang dimanfaatkan warga. Adapun beberapa pengetahuan lokal Etnis Karo terkait pengolahannya diantaranya dihasilkan dalam bentuk pembuatan minyak karo, kuning/ param, menyuntil sirih, oukup, sembur beltek, ritual erpangir ku lau dan lain-lain.

Simarmata \& Feriel (2015), tentang Oukup sebagai Pengobatan Tradisional Studi Antropologi Kesehatan Pada Masyarakat Karo, bahwa asal-mula Oukup muncul di tengah-tengah masyarakat Karo sejak lebih dari 100 tahun lalu yang dibawa oleh guru sibaso (dukun) yang mengetahui ramuan-ramuan pengobatan pada masyarakat entis Karo dan terus berkembang serta diminati masyarakat Karo dalam menyembuhkan penyakit.

Dalam penelitian yang dilakukan oleh Lubis, Nasution \& Kardhinata (2017) yang melakukan penelitian Etnobotani tumbuhan mangrove di Kawasan Kampung Nipah Dusun III Desa Sei Nagalawan Kecamatan Perbaungan Kabupaten Serdang Bedagai Sumatera Utara. Bertujuan untuk mengetahui jenis-jenis tumbuhan mangrove yang dimanfaatkan oleh tiap Etnis. Metode yang digunakan dalam penelitian ini adalah metode deskriptif dengan metode survey dan teknik wawancara semi terstruktur yaitu mengidentifikasi jenis-jenis tumbuhan mangrove yang dimanfaatkan. Penelitian yang hampir sama juga dilakukan oleh Nasution, Masitah \& Riyanto (2016). Kajian Etnobotani Tumbuhan Obat oleh Etnis Masyarakat di Dusun Aras Napal Kiri dan Dusun Aras Napal Kanan Desa Bukit Mas Kecamatan Besitang Kabupaten Langkat.

\section{METODE PENELITIAN}

Jenis penelitian yang digunakan dalam penelitian ini yaitu penelitian kualitatif dengan pendekatan deskriptif. Menurut Bogdan dan Biklen, S. (1992) penelitian kualitatif adalah salah satu prosedur penelitian yang menghasilkan data deskriptif berupa ucapan atau tulisan dan perilaku orang-orang yang diamati. Berdasarkan pengertian diatas, maka peneliti akan menggambarkan dengan detail mengenai Indigieonus Knowledge masyarakat etnis Karo terhadap pemanfaatan tumbuhan hutan di Desa Lingga Kecamatan Simpang Empat Kabupaten Karo. Adapun lokasi atau tempat penelitian berada di DesaLingga Kecamatan Simpang Empat Kabupaten Karo. Teknik pengumpulan data dilakukan dengan cara pertama, wawancara, pada penelitian ini, penulis/peneliti akan melakukan wawancara mendalam (in-depth interview).

Menurut Moleong (2005) wawancara mendalam merupakan proses menggali informasi secara mendalam, terbuka, dan bebas dengan masalah, fokus penelitian dan diarahkan pada pusat penelitian. Wawancara dilakukan langsung kepada masyarakat setempat yang masih memahami dan meracik tumbuhan hutan menjadi obat di Desa Lingga. Kedua, dokumentasi, menurut Sugiyono (2013) dokumentasi merupakan catatan peristiwa yang sudah berlalu. Pada tahap studi dokumentasi, penulis/peneliti akan mengumpulkan data dari hasil foto dan rekaman yang diperoleh dari informan dan lokasi penelitian.

Data ini, kemudian dianalisis berdasarkan temuan lapangan. Adapun jenis data yang digunakan dalam penelitian ini dibagi menjadi dua jenis, yaitu 1) data primer, data ini diperoleh dengan melakukan wawancara terhadap beberapa warga di Desa Lingga Kecamatan Simpang Empat Kabupaten Karo untuk dijadikan informan pada penelitian ini, 2) data sekunder, data ini diperoleh dari kajian pustaka dan data penunjang dari data primer seperti, artikel dan jurnal.

\section{HASIL DAN PEMBAHASAN}

\section{Indigenous Knowledge Masyarakat Etnis Karo terhadap Pemanfaatan Tumbuhan Hutan}

Pembuatan obat-obat tradisional yang bahan-bahan pembuatnya keseluruhan terbuat dari alam merupakan keahlian yang tidak bisa dimiliki sembarang orang. Pengolahan bahanbahan alam menjadi obat tradisonal ini tanpa dipengaruhi oleh bahan-bahan kimia dan takaran untuk meracik obat-obat ini hanya diketahui oleh si pembuat obat itu sendiri, karena biasanya para pembuat obat-obatan tradisional ini tidak menggunakan alat-alat pengukur takaran modern seperti alat yang digunakan saat membuat obat-obat kimia. Takaran yang digunakan untuk meracik obat-obat ini hanya berdasarkan perasaan si peracik saja, hal inilah yang salah satunya menjadi alasan mengapa obat-obat tradisional etnis Karo ini hanya ditemukan di daerah Desa Lingga saja. Takaran yang digunakan untuk meracik obat-obat tradisonal ini diperjelas dari pendapat narasumber kami Bapak Ginting Manik, yang mengatakan bahwa: 
"Labo lit ukur-ukurenna, adi aku erban tambar kuta bias me ku agak-agak saja. Perbahan aku enggo biasa erbahan tambar enda, emakana enggo nge ku eteh ukurenna ence lanai bo salah. Adi nggo pas ku akap enggo bage saja ku ban."

"tidak ada takaran yang digunakan, kalau saya membuat obat-obat tradisonal cukup saya perkirakan saja. Karena saya sudah terbiasa membuat obat-obat ini, makanya sudah saya tahu takarannya dan tidak lagi salah. Kalau saya rasa sudah pas ya sudah seperti itu saja saya buat"

Pengelolaan tanaman hutan ini menjadi berbagai jenis obat-obatan tradisional merupakan salah satu pengetahuan masyarakat di Desa Lingga. Pengetahuan masyarakat untuk mengolah dan memanfaatkan tumbuhan hutan di sekitar wilayah mereka inilah yang disebut indigenous knowledge. Pengelolaan tanaman hutan menjadi obat-obat tradisonal ini terbukti dari pendapat salah satu narasumber kami Br. Sembiring, yang mengatakan bahwa:

"Adiken adum si ipake guna erban tambar kuta enda kerinana nge ibuat kami arah kerangen. La min kerina egia buen buat kami arah kerangen, sidebanna si lalit bas kerangen emaka tukur kami arah kem-kem."

"kalau campuran yang digunakanuntuk membuat obat-obat tradisonal ini, semuanya kami ambil dari hutan. Tidak semua memang tapi kebanyakan kami ambil dari hutan, yang lainnya yang tidak ditemukan di hutan maka kami beli di kem-kem"

Dari hasil wawancara kami ini diketahui bahwa Ibu Br Sembiring memanfaatkan tanamantanaman hutan yang diolah menjadi obat-obat tradisonal. Selain itu jika tanaman yang diperlukan tidak ditemukan di hutan maka Ibu Br. Sembiring akan membelinya di Kem-kem. Kem-kem merupakan tempat yang khusus untuk menjual obat-obat tradisonal, baik berupa bahan-bahan mentah maupun bahan obat-obatan yang sudah siap jadi yang pembuatannya tanpa menggunakan bahan-bahan kimia.Toko Kem-kem ini dapat ditemuakn di daerah pasar lama Kota Kabanjahe, Kabupaten Karo.

Indigenous Knowledge yang dimiliki masyarakat Etnis Karo ini bersifat turun temurun, dari satu generasi ke generasi berikutnya, yang diwariskan langsung dari nenek moyang mereka. Uniknya meskipun diwariskan secara turun temurun dari nenek moyang yang sama, belum tentu semua anggota keluarga di generasi berikutnya yang dimaksud dapat memiliki keahlian ini, tetap saja hanya orang-orang tertentulah dalam keluarga tersebut mewariskan kemampuan dalam pembuatan obat-obat tradisional ini. Hal ini sesuai dengan pendapat salah satu narasumber kami yang ahli dalam membuat obat-obat tradisional karo, Bapak Ginting Manik, yang mengatakan bahwa:

"Adi erban tambar kuta enda, enggo nge pelajari kami arah nini bulang kami mbarenda, tapi labo kerina beluh erbansa tambar kuta enda, si beluh-beluhen nge."

"Kalau membuat obat tradisional ini, sudahnya kami pelajari dari nenek dan kakek kami dulu, tapi tidak semua bisa membuat obat tradisional ini, yang memang memiliki kemampuanlah yang bisa membuatnya"

Dari pendapat narasumber kami ini jelas diketahui bahwa pengetahuan masyarakat mengenai cara-cara membuat obat tradional dengan memanfaatkan tanaman-tanaman hutan di daerahnya berasal dari nenek moyang mereka dan diwariskan secara turun-temurun.Selain itu diketahui pula kalau dalam membuat obat-obat ini hanya orang-orang tertentulah yang bisa.

"...ue, erban tambar-tambar e nge dahinku, sababna erban tambar e la bias sada wari enca. Lenga ka kari lit adumna si man gat-gaten, lit ka kari si man kerahenken, lit ka siman tutun, ras sidebanna. Emaka arus ka nge si ban pertadingenna entahpe persedianna. Lenga pe lako tambar si pelebe arus ka nge enggo si sediaken man jaga-jaga, gelahna adi lit kari kalak rempet perlu, lit bage"

"...iya, membuat obat-obat tradisonal ininya pekerjaan saya, karena membuat obat tradisional ini tidak cukup satu hari saja. Belum lagi nanti campuran bahannya ada yang harus di iris,ada yang harus dijemur, ada pula yang harus ditumbuk, dan lain-lain. Karena itulah harus kita buat pertinggalnya atau persediaannya. Belum pun laku obat yang sebelumnya kita sudah harus menyediakan bahan-bahan lain untuk jaga-jaga, agar kalau ada annti orang tiba-tiba butuh, ada gitu" 
Dari hasil wawancara kami dengan Ibu Br Sembiring di atas, dapat diketahui bahwa obatobat tradisional ini tidak dapat dibuat dalam waktu cepat. Oleh karena itu para pembuat obat di desa ini harus sudah mulai membuat obat lagi sebelum obat yang telah dibuat sebelumnya habis terjual. Pembuatan obat-obat ini juga mempertimbangkan cuaca di desa tersebut, karena beberapa bahan yang digunakan membuat obat ini sebagian harus ada yang dijemur di bawah sinar matahari sampai kering, apabila musim penghujan maka akan sulit bagi si pembuat obat untuk mengeringkan racikan-racikannya.

Masyarakat di Desa Lingga ini masih lebih mengutamakan menggunakan obat-obat tradisonal dibandingkan dengan menggunakan obat-obat modern yang telah dicampur dengan bahan-bahan kimia. Alasan masyarakatnya lebih memilih menggunakan obat-obat tradional ini karena memang mereka sejak kecil sudah diperkenalkan dengan obat-obat tradisional. Hal ini sesuai dengan salah satu pendapat masyarakat Desa Lingga, Ibu Br. Sinulingga yang lebih memilih menjadi konsumen obat tradisonal dibandingakan obat kimia yang biasanya pengaruhnya lebih cepat dirasakan.

"kami adi lit si sakit bage tambar kuta nge lebe tukur kami, sabna tambar kuta e sieteh nge lalit risikona, emakana labo kita mbiar-mbiar mansa. Adi tambar ruma sakit ah mbiar denga kita mannsa sabna adi tambar rumah sakit banci kita banna munduk-unduk, ceda ginjalta adi mbuesa $i$ pan. Tapi adi nggo parah kel pinakitna, enggo pe man tambar kuta lenga malem emaka perlu kita ku rumah sakit."

"Kami kalau ada yang sakit, obat tradisional yang lebih dulu kami beli, karena obat tradisional ini kita tahu tidak ada efek sampingnya, maknaya kita tidak takut-takut memakannya. Kalau obat rumah skait itu kita takut memakannya karena kalau tambar rumah sakit bisa kita dibuat ngantuk, rusak ginjal kalau terlalu banyak dimakan. Tapi kalau penyakitnya sudah parah, sudah pun makan obat tradisional tapi belum sembuh juga maka perlu kita ke rumah sakit"

Dari hasil wawancara ini diketahui bahwa meskipun masyarakatnya sudah mengenal obatobat modern dan perawatan modern di rumah sakit, mereka tetap saja lebih mengutamakan mengkonsumsi obat-obat tradisional. Alasan ini terjadi karena masyarakatnya menganggap penggunaan obat-obat tradisional lebih aman diabandingkan dengan penggunaan obat-obat rumah sakit yang dinilai lebih banyak memiliki efek samping yang buruk terhadap kesehatan.

\section{Pengolahan Tumbuhan Hutan sebagai Pengobatan Tradisonal}

Sembur, Terdiri dari lada hitam, kaciwer (kencur), bahing, beras. Bahan-bahan ini di tumbuk atau digiling hingga kalis atau lumat, kemudian di oleskan pada tubuh. Namun pengolahan tradisional yang dulu dilakukan untuk membuat sembur pada etnisKaro, di kunyah langsung di mulut dan kemudian di semburkan langsung ke tubuh pasien. Mengobati penyakit sesaknapas, batuk-batuk, sakit kepala, masuk angin di perut atau di badan, dan menghilangkan pegal-pegal badan.

Obat Dalam atau Luka Dalam, terdiri dari daun lancing ${ }_{2}$ kuning telur ayam kampug ${ }_{2}$ merica $_{2}$ garam. Peracikan atau pembuatan obat tradisonal luka dalam ini membutukan tujuh lembar daun lancing, kemudian di tumbuk untuk mengambil air sari pati dari daun lancng. Setelah sari pati dari daun lancing siap kemudian campur dengan satu butir kuning telur ayam kampung, lalu merica dan garam secukupnya.Setelah tercampur semua, kemudian dapat diminum.Mengobati luka bagian dalam tubuh dan mempercepat pemulihan tubuh bagi pasien.

Parem, terdiri dari bawang merah, bawang putih, bahing (bahing merah (rasanya lebih panas) bahing putih (rasanya lebih tidak lebih panas)), buah pala, kulit jeruk purut. Tambahan untuk anak bayi, keciur (kencur), kemiri dan tambahan untuk ibu yang usai melahirkanbahing dan lada hitam (diperbanyak).Dalam peracikan atau pembuatan obat tradisonal parem ini terlebih dahulu untuk semua bahan dicuci hingga bersih, kemudian dirajang atau di iris tipistipis. Setelah selesai di iris tipis-tipis bahan baku obat tadi di jemur dibawah terik matahari hingga kandungan akan air pada bahan baku obat tersebut sudah berkurang dan dapat dikatakan kering.

Setelah semua bahan baku kering, kemudian ditumbuk hingga halus dan kalis bersama beras atau dapat dengan tepung beras. Beras disini dapat sebagai perekat dan sebagi penghalus 
pada kulit, dapat juga sebagi kosmetik menghaluskan kulit. Lalu setelah bahan selesai digiling dibentuk adonan dengan menbuat air sedikit dan kemudian dapat di bentuk lingkaran dan kemudian dijemur hingga kering di bawah sinar matahari.

Adapun jenis-jenis bentuk parem dapat kita ketauhi di gunakan kepada usia anak atau dewasa. Jika parem berbentuk bulatan dan berukuran kecil ini diperhuntukan pada anak bayi dan parem ini tidak terlalu panas sesuai untuk anak dan kulit bayi. Sedangkan pada param yang memiliki lobang berbentuk lingkaran pada tengah parem dan berukuran sedikit besar ini di perhuntukan pada usia dewasa dan parem ini memiliki tingkatan panas yang cukup panas. Pengunaan pada tubuh terlebih dahulu di larutkan atau dihancurkan ke air bersih, lalu lumurkan pada tubuh yang sakit seperti badan, sehinga seperti luluran, biarkan hingga kering. Mengobati sakit sakit kepala, masuk agin, sakit perut, menyembuhkan pegal-pegal pengaruh kerja berat, pemulihan terkilir serta pada ibu yang baru melahirkan parem ini di gunakan untuk memulihkan setamina dan menjaga kehagatan tubuh dari si ibu, pada anak kecil atau bayi parem digunaka sama halnya menjaga kehagatan tubuh dan memperkuat imun tubuh karena anak bayi masih akan rentang terkena penyakit dan paparan dari luar.

Tawar, terdiri dari jahe, bahing, rimo raga/ jeruk raga, lada, garama, kunyit, tambahan buat setamina laki-lakikelamin dari tupai (yang di sebut masyarakat setempat bersa). Semua bahan digiling atau di tumbuk seperti jahe, bahing, lada, kunyit dan kemudia semua bahan ini di rebus dengan air bersih.Penambah air rimo ragaberserta sedikit kulit jeruk sesuai takaran sebagai penambah cita rasa dan aroma wagi dan penambahan garam pada tawar untuk memperkuat cita rasa orang karo bilag "gelah tabeh". Air berserta ampas dari rembusan dan rempah-rempah ini tidak di pisahkan, ini semua di gunakan.mengobati luka dan penyakit dalam serta menambah akan setamina untuk para pengguna, menjaga imun tubuh, pegal-pegal badan. Tambahan pada peri disini seperti kelamin tupai diyakini sebagai penambah setamina dalam berhubungan intim.Namun pada umumya tawar di gunakan untuk pengobatan dalam.

Obat Mata Atau Tetes Mata, terdiri dari abu bekas bakaran, kunyit, beras rebung bamboo. Peracikan atau pembuatannya yaitu ambil kunyit dua rusa dan dicacah, rebung bambu (bukan rebung yang di konsumsi menjadi sayur yang di peroleh dari pohon bambu muda melainkan sejenis tebu monyet) dua rusa dan di potong dua atau tiga tergantung wadah yang di sediakan, lalu ambil segegam beras. Kemudian rendam semua bahan di dalam segelas air bersih, endapkan satu malam sampai terpisah air yang berwarna kuning dan putih. Setelah itu air tersebut sudah dapat digunakan dengan menetesakan air ke mata sebanyak tiga tetesa dan di gunakan dua kali sehari yaitu pagi hari sebelum beraktivitas dan malam hari pada saat mau beristirahat atau mau tidur. Namun pada saat sudah merasa baik atau sembuh tidak bisa lagi digunakan atau di hentikan saja.mengobati mata yang terkena serpihan debu, merah dan lain sebaginya. Obat ini juga di yakini masyarakat Karo sebagai obat mata yang terkena katarak.

Obat Cacar Atau Kudis Di Kepala Anak-Anak, terdiri dari biji pinang, paku perik. Peracikan atau Pembuatannya yaitu biji pinang dikunyah bersama paku perik hinga lumat di mulut kemudian semburkan atau taruh pada kudis kepala si anak. Bermanfaat untuk mengeringkan kudis pada kepala anak yang kemudian secara otomatis menyembuhkan dan membersihkan bekas-bekas dari kudis tersebut.

Membersihkan Kulit Bayi Baru Lahir, terdiri dari kemiri, kunyit, beras, daun durian, kain kasa (sebagai pembungkus). Peracikan atau pembuatannya yaitu dengan melumat atau menghaluskan semua bahan atau rempah-rempah di mulut tepatnya di kunyah seperti kunyit, kemiri, beras. Setelah lumat di taruh dan di bungkus di kain kasa. Kemudian daun durian di masukan pada rebusan air mandi. Lalu pada saat mandi rempah-rempah yang sudah di bungkus dengan kain kasa di gosokan berlahan pada tubuh bayi. Bermanfaat untuk Membersihkan kotoran-kotoran yang ada pada tubuh bayi yang baru saja lahir dan memberikan sensasi motorik dengan adanya gosokan pada kulit bayi.

Obat Luka, terdiri dari sirahra, talu daging (laki-laki bunga berwarna merah dan perempuan buanga berwarna ungu). Peracikan atau pembuatannya yaitu kedua jenis tumbuhan ini dilumat dengan kedua telapak tangan hingga mengeluarkan air atau pati dari tumbuhan 触http://mahesainstitute.web.id/ojs2/index.php/jehss 
tersebut. Kemudian serat dan sari patih dari tumbuhan ini di taruh pada luka. Manfaatnya sebagai sebagai anti biotik dan mempercepat penyembuhan dari luka.

Menjaga Pinggang Pada Saat Bayi Belajar Berjalan, terdiri dari daun cipluk, lemak ayam kampong asli, garam, pinang, daun pisang atau daun ropah (jipang). Peracikan atau pembuatannya yaitu semua rempah di bungkus di daun pisang dan di bakar pada bara api. Kemudian dapat diambil atau siap di gunakan pada saat daun pisang sudah terlihat gosong dan dari rempah-rempah sudah mengeluarkan wewangian. Setelah itu campur dengan minyak lalu oles ke pingang bayi. Manfaatnya untuk menjaga pingang dan kontuksi tulang dari bayi pada saat belajar berjalan, karena pada saat berjalan bayi tak jarang jatuh atau terbentur.

Obat Terkilir, terdiri dari daun lancing seberani-seberani galkal tebu merah. Peracikan atau pembuatannya yaitu daun Lancing, seberani-seberani dan galkal di tumbuk dan di ambil sari patinya dan kemudian air tebu merah dan kemudian di satukan pada minyak. Kemudian di oleskan pada bagian tubuh yang terkilir. Manfaatnya untuk mengobati bagian tubuh yang terkilir

\section{SIMPULAN}

Indigenous Knowledge yang dimiliki masyarakat Etnis Karo ini bersifat turun temurun, dari satu generasi ke generasi berikutnya, yang diwariskan langsung dari nenek moyang mereka. Uniknya meskipun diwariskan secara turun temurun dari nenek moyang yang sama, belum tentu semua anggota keluarga di generasi berikutnya yang dimaksud dapat memiliki keahlian ini, tetap saja hanya orang-orang tertentulah dalam keluarga tersebut mewariskan kemampuan dalam pembuatan obat-obat tradisional ini. Terdapat berbagai macam obat-obatan yang diracik oleh masyarakat etnis Karo dari tumbuhan hutan di sekitar Desa Lingga dengan menggunakan cara, alat dan bahan sederhana yang digunakan menjadi obat berbagai jenis penyakit, mulai dari penyakit ringan, seperti sakit kepala, batuk, masuk angin, dan lain-lain hingga kepada penyakit yang memerlukan penanganan serius, seperti luka dalam akibat kecelakaan, dan lain-lain. Adapun jenis obat-obatan yang dimaksud antara lain: sembur, obat dalam atau luka dalam, parem, tawar, obat mata, obat cacar, membersihkan kulit bayi baru lahir, obat luka, menjaga pinggang bayi saat belajar berjalan, dan obat terkilir.

\section{DAFTAR PUSTAKA}

Adelia, N. (2016). Pustakawan dan Pengetahuan Tradisional: Studi Tentang Urgensi dan Peran Pustakawan dalam Pengetahuan Tradisional.Record and Library. 2(1): 51-57

Ahimsa-Putra, H. S. (1985). Etnosains dan Etnometodologi: Sebuah Perbandingan.Masyarakat Indonesia. Tahun ke-XII (No.2): 103-133.

Aini, D. C. (2012). Telaah Yuridis Ketentuan Perlindungan Pengetahuan Tradisional dalam Hukum Internasional.Tesis Pascasarjana Universitas Indonesia.

Anwar, M. A. (2010). Evaluasi Kinerja SDM. Bandung: Refika Aditama.

Bogdan, R. C. \& Biklen, S. K. (1992). Qualitative Research for Education: An Introduction to Theory and Metdhos. Boston: Allyn and Bacon.

Iswandono, E. dkk. (2015). Pengetahuan Etnobotani Suku Manggarai dan Implikasi Terhadap Pemanfaatan Tumbuhan Hutan di Pegunungan Ruteng. Ilmu Pertanian Indonesia. 20(3): 171-181

Jangawa, M. (2007). Challenges and opportunities in the protection and preservation of indigenous knowledge in Africa. Dikutip dari online dihttp://www.africainfoethics.org/pdf/african_reader/46\%20ICIE\%20Chapter\%2038\%20pa ge\%20343-349.pdf

Lubis, R. Nasution, J. \& Kardhinata, E.H. (2017). Kajian Etnobotani Tumbuhan Mangrove oleh Masyarakat Kampung Nipah Dusun III Desa Sei Nagalawan Kecamatan Perbaungan Kabupaten Serdang Bedagai Sumatera Utara, Jurnal Biosains Vol 3, No 1: 9 - 13.

Moleong, L.J. (2005). Metode Penelitian Kualitatif. Bandung: Remaja Rosdakarya.

Murni, S.A. dkk. (2012). Eksistensi Pemanfaatan Tanaman Obat Tradisional (TOT) Suku Serawai Medikalisasi Kehidupan. Penelitian Pengelolaan Sumberdaya Alam dan Lingkungan. 1 (3): 225-234.

Nasution, J. Masitah, P.D. \& Riyanto (2016). Kajian Etnobotani Tumbuhan Obat oleh Etnis Masyarakat di Dusun Aras Napal Kiri dan Dusun Aras Napal Kanan Desa Bukit Mas Kecamatan Besitang Kabupaten Langkat, Jurnal Biosains Vol 2, No 2 (2016): 91 - 96.

Palupi. N. P. (2013). Kearifan Lokal Tanaman Obat Masyarakat Dayak di Kabupaten Nunukan Kalimantan Timur. AGRIFOR. 12(1): 83-95. 
Pandapotan, S. Khairat \& Syahril. (2018). Inventarisasi Kearifan Lokal Etnis Karo dalam Pemanfaatan Etnobotani di Kabupaten Karo. Journal of Education, Humaniora and Social Sciences (JEHSS). 1 (1): 43-50.

Rahayu, M. dkk. (2006). Pemanfaatan Tumbuhan Obat Secara Tradisional Oleh Masyarakat Lokal di Pulau Wawoni, Sulawesi Tenggara. Biodiversitas. 7(3): 245-250.

Simarmata, T dan Feriel, A.S. (2015). Oukup Sebagai Pengobatan Tradisional Studi Antropologi Kesehatan Pada Masyarakat Karo, Anthropos: Jurnal Antropologi Sosial dan Budaya, 1 (1): 34-41.

Sugiyono. (2013). Metode Penelitian Pendidikan Pendekatan Kuantitatif, Kualitatif, dan R\&D. Bandung: Alfabeta. 